\title{
PERAN RASIO KEUANGAN DAN KINERJA KEUANGAN PERUSAHAAN
}

\author{
Bintang Ramadani Putra1 ${ }^{1}$, Mohammad Benny Alexandri² \\ ${ }^{1,2}$ Universitas Padjadjaran \\ bintangramadani.brp@gmail.com ${ }^{1}$, bennyalexandri@yahoo.co.id ${ }^{2}$
}

\begin{abstract}
ABSTRAK
Penelitian ini bertujuan untuk (1) bagaimana manfaat dari analisis rasio keuangan?(2) bagaimana rasio keuangan dapat memprediksi peringkat obligasi (3) bagaimana rasio keuangan dapat memprediksi distress pada perbankan (4) bagaimana rasio keuangan dapat memprediksi perubahan laba rugi (5) bagaimana rasio keuangan dapat menunjukan pengaruh merger terhadap kinerja keuangan. Hasil penelitian Seperangkat rasio keuangan (leverage, likuiditas, solvabilitas, profitabilitas dan produktivitas) mempunyai kemampuan membentuk model untuk memprediksi peringkat obligasi. Suatu rasio tidak memiliki arti jika berdiri sendiri, melainkan harus dibandingkan dengan rasio keuangan pada periode sebelumnya sehingga dapat mengetahui kecenderungan selama periode tertentu. Selain dibandingkan dengan rasio periode sebelumnya dapat juga dibandingkan dengan rasio keuangan dari perusahaan lain dengan jenis perusahaan yang sama.

Kata Kunci : Rasio Keuangan, Analisis, Distress, Laba Rugi
\end{abstract}

\begin{abstract}
This study aims to (1) how are the benefits of financial ratio analysis? (2) how financial ratios can predict bond ratings (3) how can financial ratios predict distress in banking (4) how can financial ratios predict changes in income (5) how financial ratios can show the effect of the merger on financial performance. Research Results A set of financial ratios (leverage, liquidity, solvency, profitability and productivity) has the ability to form models to predict bond ratings. A ratio has no meaning if it stands alone, but must be compared with financial ratios in the previous period so that we can find out trends during a certain period. Apart from being compared with the ratios of the previous period, it can also be compared with the financial ratios of other companies with the same type of company.
\end{abstract}

Keywords: Financial Ratios, Analysis, Distress, Profit and Loss

\section{PENDAHULUAN}

Masalah keuangan merupakan salah satu masalah yang sangat vital bagi perusahaan dalam perkembangan bisnis disemua perusahaan. Salah satu tujuan utama didirikannya perusahaan adalah untuk memperoleh keuntungan yang maksimal.
Namun berhasil tidaknya perusahaan dalam mencari keuntungan dan mempertahankan perusahaannya tergantung pada manajemen keuangan. Perusahaan harus memiliki kinerja keuangan yang sehat dan efisien untuk mendapatkan keuntungan atau laba serta 
perusahaan dapat bertahan dengan waktu yang lama.

kinerja perusahaan adalah proses pengkajian secara kritis terhadap keuangan perusahaan untuk memberikan solusi dalam pengambilan suatu keputusan yang tepat pada suatu periode tertentu. Analisis laporan keuangan menggunakan perhitungan rasiorasio agar dapat mengevaluasi keadaan finansial perusahaan dimasa lalu, sekarang, dan masa yang akan datang.

Salah satu alat untuk mengukur kinerja perusahaan baik atau buruk adalah laporan keuangan yang disajikan secara teratur setiap periode (Juliana dan Sulardi, 2003). Analisis rasio keuangan merupakan teknik analisis laporan keuangan dengan cara membandingkan satu komponen dengan komponen lainnya yang ada dalam laporan keuangan (neraca, laporan laba/rugi, laporan arus kas). Kemudian Rasio keuangan dibandingkan dengan rasio keuangan tahun sebelumnya atau dibandingkan dengan rasio keuangan dari perusahaan lain dengan jenis industri yang sama.

Analisis laporan keuangan mempunyai ruang lingkup yang sangat luas dan untuk membatasi ruang lingkup permasalahan di atas, maka penulis hanya akan membahas tentang bagaimana rasio keuangan dapat mengetahui masa depan perusahaan dan untuk mengetahui manfaatmanfaat dari rasio keuangan itu sendiri. Adapun penulis menggunakan penelitian deskriptif dengan metode kualitatif .

\section{Rumusan masalah}

Berdasarkan latar belakang masalah tersebut pokok permasalahannya adalah:

1. Apa manfaat dari analisis rasio keuangan?

2. Bagaimana rasio keuangan dapat memprediksi peringkat obligasi ?

3. Bagaimana rasio keuangan dapat memprediksi distress pada perbankan?
4. Bagaimana rasio keuangan dapat memprediksi perubahan laba rugi ?

5. Bagaimana rasio keuangan dapat menunjukan pengaruh merger terhadap kinerja keuangan?

\section{METODE PENELITIAN}

Metode penelitian pada resume jurnal ini dilakukan secara kualitatif yang bertujan untuk memperoleh dan meringkas informasiinformasi penting terkait dengan jurnal-jurnal yang bersangkutan.

\section{Populasi dan Sampel}

Populasi pada resume jurnal yang dilakukan oleh peneliti adalah seluruh jurnal yang memiliki topik mengenai rasio keuangan.

Sampel yang diambil oleh peneliti adalah lima judul jurnal yang memiliki relevansi topic di bindang rasio keuangan.

\section{PEMBAHASAN}

\section{Rasio Keuangan Sebagai Alat Untuk Memprediksi Tingkat Obligasi}

Salah satu bentuk pendanaan yang dapat dilakukan oleh suatu perusahaan untuk membiayai investasinya adalah dengan menerbitkan obligasi. Obligasi selain digunakan sebagai sarana melakukan ekspansi juga dapat digunakan sebagai sarana dalam memperkuat permodalan bagi perusahaan. Obligasi adalah surat berharga dalam bentuk sertifikat yang berisi kontrak antara pemberi pinjaman (investor) dengan yang diberi pinjaman (emiten). Obligasi bagi investor merupakan media investasi alternatif diluar deposito bank,sedangkan bagi emiten obligasi ini merupakan media sumber dana diluar kredit perbankan.

Pemodal dan investor yang berminat membeli obligasi harus memperhatikan beberapa hal,salah satunya adalah peringkat obligasi. Peringkat obligasi merupakan skala risiko dari semua obligasi yang diperdagangkan. Skala tersebut menunjukkan tingkat keamanan suatu 
obligasi bagi investor. Keamanan ini ditunjukkan oleh kemampuan emiten (sebagai penerbit obligasi) dalam membayar bunga dan pelunasan pokok obligasi pada akhir masa jatuh temponya. Peringkat obligasi sangat penting karena mampu memberikan pernyataan informatif dan memberikan signal tentang probabilitas kegagalan utang suatu perusahaan (Altman and Nammacher dalam Ketz and Maher, 1990).

Berdasarkan penelitian-penelitian tersebut, maka penelitian ini bertujuan untuk menguji kembali variabel-variabel (rasio keuangan) manakah yang mempunyai kemampuan dan yang signifikan dalam membentuk model untuk memprediksi peringkat obligasi di Indonesia. Selain itu penelitian ini juga menguji perbedaan model statistik untuk memprediksi peringkat obligasi. Peneliti akan menguji apakah dengan menggunakan dua teknik analisis yang berbeda (analisis diskriminan dan regresi logistik) akan memperoleh hasil yang sama ataukah berbeda. Penelitian ini diharapkan dapat memberi

Manfaat bagi praktisi dan akademisi. Bagi praktisi, bila bukti empiris yang dihasilkan dari model prediksi yang diajukan oleh peneliti adalah baik, maka dapat digunakan oleh perusahaan dan investor untuk memverifikasi peringkat obligasi yang dikeluarkan oleh agen PEFINDO. Bagi agen pemeringkat obligasi, dalam hal ini khususnya agen PEFINDO sebagai pembanding dan pertimbangan dalam memprediksi peringkat obligasi. Sementara itu bagi akademisi, penelitian ini diharapkan dapat memberikan kontribusi untuk pengembangan model prediksi peringkat obligasi di masa yang akan datang, khususnya mengenai kemampuan rasio keuangan dalam memprediksi peringkat obligasi perusahaan di Indonesia.

Rasio profitabilitas yang diproksikan dengan 5 rasio, terdapat 1 rasio yang tidak signifikan yaitu rasio PRFCOFTS. Hasil signifikan rasio
PRFOIS konsisten dengan penelitian Horrigan (1966), S\&P (1994) dalam Sulistyastuti (2002) tetapi berbeda hasil dengan penelitian Nurhasanah (2003). Sedangkan signifikannya rasio PRFNIATTA konsisten dengan penelitian Pinches and Mingo (1973).

Rasio produktivitas yang diproksikan dengan 4 rasio semuanya menunjukkan asymp. Sig (2-tailed) $<0,05$. Hasil yang signifikan dari rasio PRODSTA konsisten dengan penelitian Nurhasanah (2003) tetapi berbeda hasil dengan Horrigan (1966). Rasio PRODSFA konsisten dengan penelitian S\&P (1994) dalam Sulistyastuti (2002), Kesumawati (2003) dan Sari (2004). Hasil uji Mann Whitney menunjukkan dari 22 rasio keuangan terdapat 20 rasio keuangan yang berbeda secara signifikan antara perusahaan yang obligasinya masuk kategori investment grade dan non-investment grade. Hal ini dapat dibuktikan dengan melihat nilai asymp.

Sig (2-tailed) lebih kecil dari 0,05. Sedangkan 2 rasio keuangan lainnya tidak dapat membedakan kedua kategori karena nilai asymp. Sig (2-tailed) lebih besar dari 0,05. Kadua rasio keuangan tersebut adalah net worth to long-term liability (NWLTL) dengan nilai asymp. Sig (2-tailed) sebesar 0,117 dan cash flow from operating to total sales (CFOTS) dengan nilai asymp. Sig (2-tailed) sebesar 0,143. Dengan melihat hasil pengujian secara keseluruhan maka dapat disimpulkan hipotesis pertama (H1) diterima.

\section{Rasio Keuangan Sebagai Alat Memprediksi Perubahan Laba Pada Perusahaan Property di BEI dan SGX}

Riset mengenai analisis rasio keuangan dimulai oleh penelitian Venus C. Ibarra (2009), Meythi (2005) dan Nurjanti Takarini 
\& Erni Ekawati (2003) memberikan bukti empiris yang mendukung analisis rasio keuangan dalam memprediksi perubahan laba perusahaan yang sudah ada sebelumnya dan memberikan hasil yang beragam dan signifikan. Sehingga penelitian ini dilakukan di Bursa Efek Indonesia dan Singapura karena sejauh ini, penelitian yang membandingkan analisis rasio keuangan dalam memprediksi perubahan laba di Bursa Efek Indonesia dan Singapura belum ada di Indonesia. Populasi dalam penelitian ini adalah perusahaan Real Estate dan property yang terdaftar di Bursa Efek Indonesia dan Singapura yang mempublikasikan laporan keuangan per-31 desember dan merupakan laporan yang telah di audit.

Rumusan masalah dalam penelitian ini apakah analisis rasio keuangan dapat digunakan untuk memprediksi perubahan laba pada perusahaan Real Estate dan Property yang terdaftar di Bursa Efek Indonesia (BEI) dan Singapura (SGX) dan apakah ada perbedaan analisis rasio keuangan untuk memprediksi perubahan laba pada perusahaan Real Estate dan Property antara Bursa Efek Indonesia (BEI) dan Singapura (SGX). Tujuan penelitian ini untuk memberikan bukti empiris apakah analisis rasio keuangan berpengaruh dalam memprediksi perubahan laba dan apakah terdapat perbedaan analisis rasio keuangan yang berpengaruh dalam memprediksi perubahan laba pada perusahaan real estate dan property di Bursa Efek Indonesia (BEI) dan Singapura (SGX).

Berdasarkan hasil pengujian hipotesis dengan uji F semua variabel independen analisis rasio keuangan (rasio lancar, perputaran total aktiva, total hutang terhadap total aset, profit margin, ROA, dan ROE)

berpengaruh signifikan dalam memprediksi perubahan laba pada perusahaan real estate dan properti di Bursa Efek Indonesia (BEI) tahun 2004-2009. Sedangkan berdasarkan hasil Uji t dapat disimpulkan bahwa Rasio likuiditas (rasio lancar) dan rasio profitabilitas (profit margin) berpengaruh signifikan dalam memprediksi perubahan laba pada perusahaan real estate dan property di Bursa Efek Indonesia (BEI) tahun 2004-2009. Sedangkan Rasio Aktivitas (perputaran total aktiva); Rasio Solvabilitas (total hutang terhadap total aset) dan profitabilitas (ROA dan ROE) memiliki pengaruh yang tidak signifikan dalam memprediksi perubahan laba pada perusahaan real estate dan properti di Bursa Efek Indonesia (BEI).

Berdasarkan hasil analisis uji Chow test yang dapat diketahui dari tabel $\mathrm{F}$ dengan $\mathrm{df}=2$ dan 129 tingkat signifikansi 0,05 didapat nilai $\mathrm{F}$ tabel 3.07. Oleh karena $\mathrm{F}$ hitung $>\mathrm{F}$ tabel (11.647 > 3.07) maka disimpulkan bahwa terdapat perbedaan analisis rasio keuangan (rasio lancar, perputaran total aktiva, total hutang terhadap total aset, profitmargin, ROA, dan ROE) yang berpengaruh dalam memprediksi perubahan laba dariperusahaan real estate dan property di Bursa Efek Indonesia (BEI) dan Singapura (SGX) tahun 2004-2009.

\section{Manfaat Rasio Keuangan Dalam Memprediksi Financial Distress Pada Perbankan (2007-2012)}

Financial distress adalah kondisi suatu perusahaan yang terjadi sebelum kebangkrutan. Suatu perusahaan dikatakan sedang berada dalam keadaan financial distress apabila perusahaan tersebut tidak mampu atau mengalami kesulitan dalam membiayai kewajiban keuangannya dan menghasilkan laba yang negatif. Foster dalam Almilia dan Kristijadi (2003: 7) menyatakan beberapa indikator atau sumber informasi mengenai kemungkinan dari kesulitan keuangan, antara lain:

1. Analisis arus kas untuk periode sekarang dan yang akan datang. 
2. Analisis strategi perusahaan yang mempertimbangkan pesaing potensial, struktur biaya relatif, perluasan rencana dalam industri, kemampuan perusahaan untuk meneruskan kenaikan biaya, kualitas manajemen dan lain sebagainya.

3. Analisis laporan keuangan dari perusahaan serta perbandingannya dengan perusahaan lain.

4. Variabel eksternal seperti return sekuritas dan penilaian obligasi.

Laporan keuangan bank dapat dimanfaatkan dalam memprediksi kondisi keuangan atau tingkat kesehatan bank. Laporan keuangan memberikan informasi tentang hasil-hasil usaha yang telah diperoleh pada waktu tertentu serta biaya-biaya usaha yang dikeluarkan dalam rangka menjalankan kegiatan operasional dan kegiatan manajerial bank melalui laporan laba rugi bank. Analisis manfaat rasio keuangan dapat dilakukan dengan melihat rasio-rasio keuangan bank yang tersaji dalam laporan keuangan bank yang bersangkutan.

Almilia dan Herdiningtyas (2005) melakukan penelitian manfaat rasio CAMEL dalam memprediksi kondisi bermasalah pada bank. Rasio yang digunakan adalah CAR, Aktiva Produktif Bermasalah (APB), NPL, PPAPAP, ROA, NIM dan BOPO. Hasil penelitian menunjukkan bahwa rasio CAR dan BOPO adalah rasio yang memiliki pengaruh positif signifikan terhadap kondisi bermasalah bank. Christina Kurniasari (2013) melakukan

Performing Loan (NPL). Adapun hipotesis yang digunakan adalah:

H1 : Rasio CAR memiliki pengaruh positif terhadap prediksi financial distress bank.

H2 : Rasio ROA memiliki pengaruh positif terhadap prediksi financial distress bank.

H3 : Rasio ROE memiliki pengaruh negatif terhadap prediksi financial distress bank. H4 : Rasio LDR memiliki pengaruh negatif terhadap prediksi financial distress bank.
H5 : Rasio BOPO memiliki pengaruh positif terhadap prediksi financial distress bank.

1. Model regresi logistik dengan menggunakan rasio keuangan 1 tahun sebelum financial distress bukan merupakan model regresi yang baik karena model regresi tersebut belum fit dengan data. Sedangkan model regresi logistik dengan menggunakan rasio keuangan 2 tahun sebelum financial distress merupaka model regresi logistik yang baik karena model telah fit dengan data.

2. Model rasio keuangan 2 tahun sebelum financial distress yang digunakan mampu memprediksi bank financial distress dan bank tidak financial distress sebesar 70,8\%.

3. Capital Adequacy Ratio (CAR) 2 tahun sebelum financial distress memiliki pengaruh positif tetapi tidak signifikan dalam memprediksi financial distress. Hasil penelitian ini berbeda dengan hasil penelitian yang dilakukan oleh Almilia dan Herdiningtyas (2005) yang menemukan bahwa CAR memiliki pengaruh negatif dan signifikan dalam memprediksi financial distress pada bank periode 2000-2002.

4. Rasio Return on Asset (ROA) 2 tahun sebelum sfinancial distress memiliki pengaruh negatif tetapi tidak signifikan terhadap prediksi financial distress. Hasil penelitian ini sesuai dengan hasil penelitian yang dilakukan oleh Almilia dan Herdiningtyas (2005) pada periode 2000-2002.

5. Rasio Return on Equity (ROE) 2 tahun sebelum financial distress memiliki pengaruh negatif tetapi tidak signifikan terhadap prediksi financial distress. Hasil penelitian ini sesuai dengan hasil penelitian yang 
dilakukan oleh Prasetyo (2011) pada periode 2006-2008.

6. Rasio Loan to Deposit Ratio (LDR) 2 tahun sebelum financial distress memiliki pengaruh negatif tetapi tidak signifikan terhadap prediki financial distress. Hasil penelitian ini sesuai dengan hasil penelitian yang dilakukan oleh Martharini (2012) pada periode 2006-2010.

\section{SIMPULAN}

1. Seperangkat rasio keuangan (leverage, likuiditas, solvabilitas, profitabilitas dan produktivitas) mempunyai kemampuan membentuk model untuk memprediksi peringkat obligasi.

2. Terdapat perbedaan analisis rasio keuangan (rasio lancar, perputaran total aktiva, total hutang terhadap total aset, profitmargin, ROA, dan ROE) yang berpengaruh dalam memprediksi perubahan laba dariperusahaan real estate dan property di Bursa Efek Indonesia (BEI) dan Singapura (SGX) tahun 2004-2009.

3. Rasio LDR dan BOPO adalah rasio yang memiliki pengaruh positif signifikan dalam memprediksi financial distress pada perbankan di Indonesia. Sedangkan rasio CAR, NPL, ROA, dan ROE tidak memiliki pengaruh yang signifikan dalam memprediksi financial distress pada perbankan.

4. Suatu rasio tidak memiliki arti jika berdiri sendiri, melainkan harus dibandingkan dengan rasio keuangan pada periode sebelumnya sehingga dapat mengetahui kecenderungan selama periode tertentu. Selain dibandingkan dengan rasio periode sebelumnya dapat juga dibandingkan dengan rasio keuangan dari perusahaan lain dengan jenis perusahaan yang sama.

\section{DAFTAR PUSTAKA}

1. Sari MJ. (2007). Kemampuan Rasio Keuangan Sebagai Alat Untuk Memprediksi Peringkat Obligasi ( $\mathrm{Pt}$ Pefindo), Vol. 14, No.2, 172-182, 11 September 2018.

2. Siregar RI., Fauzie S.(2012). Analisis Manfaat Rasio Keuangan Dalam Memprediksi Financial Distress Pada Perbankan (2007-2012), Vol.2, No.12, 717-726,

3. Suwarno AE., (2004). Manfaat Informasi Rasio Keuangan dalam Menprediksi Perubahan Laba, Vo.3, No.2, $127-$ 152, http://journals.ums.ac.id/index.p hp/reaksi/article/download/3599/2282 , 11 September 2018.

4. Wibowo AH., Pujiati D.(2011). Analisis Rasio Keuangan Dalam Memprediksi Perubahan Laba Pada Perusahaan Real Estate Dan Property Di Bursa Efek Indonesia (Bei) Dan Singapura (Sgx), Vol.1, No.2, 155178, 11 September 2018.

5. Setiawati L., Siregar SL.(2006). Analisis Rasio Keuangan Untuk Menunjukkan Pengaruh Merger Terhadap Kinerja Keuangan Perusahaan Studi Kasus : Pt. Indofood Sukses Makmur,

6. Alam Herjayanto, Bintang Ramadhani Putra, Shabrina Maulidiyah Rahmah (2018) Manfaat Rasio Keuangan 